\title{
The continuity of learning in a translanguaging science classroom
}

\author{
Annika Karlsson $^{1}$ (D) P Pia Nygård Larsson ${ }^{1} \cdot$ Anders Jakobsson $^{1}$
}

Received: 3 October 2018 / Accepted: 20 February 2019 / Published online: 17 May 2019

(C) The Author(s) 2019

\begin{abstract}
This article aims to explore and clarify how students' use of first and second languages in a translanguaging science classroom (TSC) may affect the continuity of learning in science. In a TSC, participants can use all available language resources, in all meaning-making situations. An ethnographic data collection and research design is used to capture the authentic language use in this practice. The study followed monthly science lessons at a primary school for 3 years (2012-2015) and was documented by four video cameras and four audio recorders. The data material also consists of recorded conversations with four students, newly arrived in Sweden at the time of the data collection. In addition, field notes, students' texts and different teaching materials were collected. To analyze how the use of both first and second languages may affect the continuity of science learning in multilingual classroom activities, practical epistemology analysis is used. The analysis shows that a TSC is an asset in appropriating a new social practice for students with limited ability to understand and express themselves in the language of instruction. However, the analysis also reveals some situations within this practice, in which all available resources are not utilized. These situations seem to be consequences of low expectations of students with limited access to the language of instruction expressed in simplified language usage; contextualizing the subject matter to everyday experiences students may not share; and the complexity of translating and transforming scientific content from one national language into another (Arabic and Swedish) and between everyday and academic discourse. The study contributes to the field by illustrating the importance of supporting each student's access to the language tools that constitutes the scientific subject matter, as well as promoting the use of all resources to relate this to prior experience for a continuity of learning in a multilingual science classroom.
\end{abstract}

Keywords Appropriation - Continuity of science learning in multilingual classroom activities · Discursive languages $\cdot$ Language games $\cdot$ Translanguaging science classrooms

Lead Editor: Jesse Bazzul.

Annika Karlsson

annika.karlsson@mau.se

1 Education and Society, Malmö University, 20506 Malmö, Sweden 
Sammanfattning Syftet med denna artikel är att undersöka och förtydliga på vilka sätt elevers användning av första- och andraspråket i ett translanguaging science classroom (TSC) utgör en resurs i meningsskapande klassrumsaktiviteter och på vilka sätt detta kan påverka kontinuiteten i flerspråkiga elevers lärande i naturvetenskap. I ett TSC är det möjligt för både lärare och elever att använda alla tillgängliga språkliga resurser, såsom exempelvis första- och andraspråk, gester, bilder och föremål, i syfte att skapa förståelse.

För att synliggöra elevernas och studiehandledarens autentiska språkanvändning i ett TSC använder vi oss av en etnografisk datainsamling och forskningsdesign. Studien följer några NO-lektioner varje månad i en mellanstadieklass under tre års tid (2012-2015). Lektionerna dokumenteras med hjälp av fyra videokameror och fyra diktafoner och den totalt inspelade tiden från lektionerna är 117 timmar. Dessutom samlas fältanteckningar, elevtexter och olika undervisningsmaterial in. Datamaterialet består också av inspelade samtal med fyra elever som vid tillfället för datainsamlingen är nyanlända. I dessa samtal berättar fyra nyanlända elever om sina erfarenheter och upplevelser av tidigare skolgång och mötet med den svenska NO-undervisningen.

I studien används practical epistemology analysis (PEA) som analysverktyg för att analysera på vilka sätt användningen av både första- och andraspråket kan påverka kontinuiteten i meningsskapande klassrumsaktiviteter i ett TSC och därmed flerspråkiga elevers möjligheter till lärande i naturvetenskap. Analysen visar att elevernas och studiehandledarens användning av första- och andraspråket utgör en resurs för de nyanlända eleverna i approprieringen av klassrumsaktiviteterna i detta NO-klassrum. Eleverna och studiehandledaren använder ofta första- och andraspråket för att förtydliga ämnesinnehåll och förklara olika aktiviteter. Emellertid avslöjar analysen också situationer i denna praktik där alla tillgängliga resurser inte utnyttjas och kontinuiteten i klassrumsaktiviteterna blir avbruten på olika sätt. Dessa situationer verkar vara konsekvenser av låga förväntningar på elever med begränsad tillgång till undervisningsspråket, vilket uttrycks i en förenkling av det språk som används, kontextualisering av ämnesinnehållet till vardagliga erfarenheter som kanske inte delas av alla elever, samt komplexiteten att översätta och transformera det naturvetenskapliga ämnesinnehållet från ett språk till ett annat (arabiska och svenska) och mellan en vardaglig och en mer akademisk diskurs. Resultatet visar att det finns en tendens att förenkla språket, både på svenska och arabiska. Detta antyder att alla de språkliga resurser som finns att tillgå i en praktik som använder och uppmuntrar translanguaging inte utnyttjas fullt ut, vilket resulterar i att eleverna inte får tillgång till de medierande resurser som konstituerar ämnesinnehållet. En annan orsak till att kontinuiteten i lärprocessen ibland blir störd är att lärarna förklarar det naturvetenskapliga ämnesinnehållet och dess specifika språkbruk genom att relatera detta till en vardaglig och praktisk kontext. Detta blir ofta problematiskt dels eftersom lärarna och elevernas vardagliga och kulturella erfarenheter till en viss del förefaller skilja sig åt och dels därför att elevernas vardagliga och kulturella erfarenhet vanligen konstitueras på ett annat språk än undervisningsspråket. Elevernas språkliga repertoar innefattade inte därför alltid de språkbruk som konstituerar en vardaglig kontext på undervisningsspråket.

Studien bidrar till fältet genom att illustrera vikten av att stödja varje elevs tillgång till de språkliga verktyg som konstituerar det naturvetenskapliga ämnesinnehållet, samt främja användningen av alla tillgängliga resurser, såsom första- och andraspråket och multimodala resurser, för att relatera det naturvetenskapliga ämnesinnehållet till tidigare erfarenhet och därmed skapa ett kontinuerligt lärande i flerspråkiga NO-klassrum. 


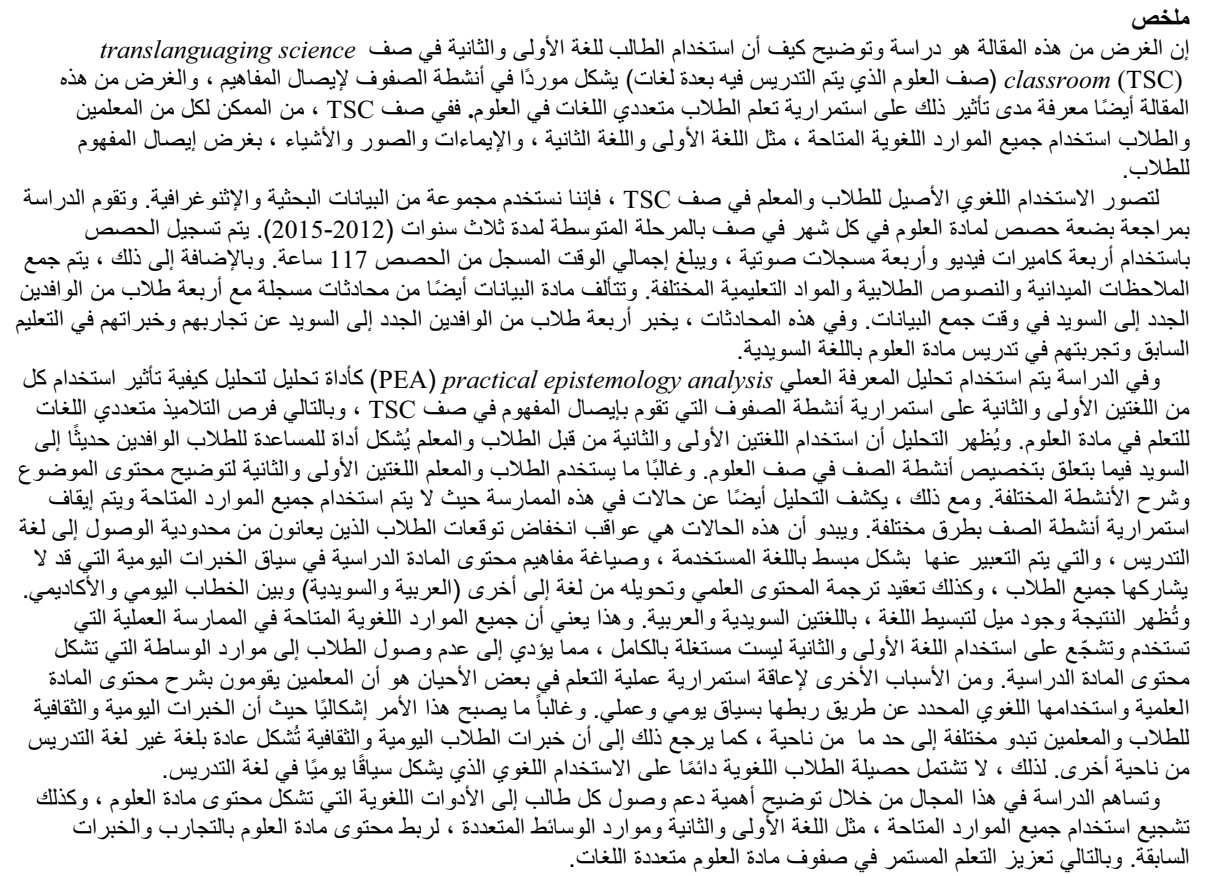

Globalization contributes to an increasing proportion of students gaining access to several different national languages. This means that an exchange of prior experience between different cultures and countries leads to brand new opportunities. However, there is a question as to how these opportunities are utilized in science education from a worldwide perspective. Cory Buxton and Okhee Lee's (2014) research review concerning English learners in science education indicates that most science teachers rarely take advantage of these opportunities which students' many experiences bring to the classroom. Moreover, according to Lee (2005), most teachers have limited experience and professional knowledge about how science instruction could be organized to support multilingual students' needs for developing their language and conceptual knowledge. In science classrooms worldwide, most students have a mother tongue other than the language of instruction. Therefore, there is a risk that the subject content will be adapted to students' linguistic abilities in the language of instruction, rather than an age-appropriate cognitive level (Cummins 2017). Evelien Van Laere, Koen Aesaert and Johan Van Braak (2014) argue that reducing expectations and requirements of students' abilities risks leading to that difficult concepts are sorted out, and hence, the subject content is simplified. This tends to lead to a downward spiral (Hajer and Meestringa 2014) that limits the opportunities for multilingual students to appropriate the science content and the subject-specific language or to challenge it on the basis of prior experience and abilities. In this context, the concept of appropriation implies that an individual or a group of individuals embrace something new from the outside world, such as a new language use, and make this their own.

Furthermore, appropriating the subject-specific language is a complex and continuous process for all students (e.g., Warren, Ballenger \& Ogonowski, et al. 2001). This brings 
another dimension into the multilingual science classroom, since research shows that it takes 5-10 years for a newly arrived student to appropriate the academic and subjectspecific language used in education (Thomas and Collier 1997). Therefore, how should science education be designed and organized to provide continuous science learning for students who have limited opportunities to understand and express themselves in the language of instruction so that all students can develop a "desire to continue learning" (Dewey 1938/1997, p. 29)?

In a translanguaging science classroom-TSC (Karlsson, Nygård Larsson and Jakobsson 2018) - in which both teachers and students can use all available language resources in all meaning-making situations (García and Wei 2014), multilingual students are provided greater opportunity to relate and contextualize the science subject matter to prior experience (Karlsson, Nygård Larsson and Jakobsson 2016). In addition, students' ability to understand the semantic relationships between scientific words and concepts seems to increase (Karlsson et al. 2018), which is important when relating these in larger thematic patterns (Lemke 1990). Furthermore, another study, conducted by Zeynap Ünsal, Britt Jakobson, Bengt-Olov Molander and Per-Olof Wickman (2017), indicates that translanguaging practices in multilingual science classrooms increase the ability of students with limited possibility to express themselves in the language of instruction to argue, discuss and explain their ideas. In this way, translanguaging contributes in that all students' prior experience can be intertwined with the educational science discourse and empower science education, which is an important element in successful science education (Tan, Barton Calabrese, Turner and Gutiérrez 2012). However, from a critical point of view, this also includes an exploration of eventual areas in this practice that need developing.

Accordingly, this article aims to further investigate and illustrate the opportunities that a TSC creates for multilingual students' abilities to appropriate the ways of speaking, thinking and acting in a science classroom, but also the obstacles that can arise in such practice and in what ways this can affect the continuity of science learning in multilingual classroom activities. The continuity of science learning may be created when students succeed in deepening and broadening their knowledge by relating the new content to their prior experiences, which means that the activity can continue in a meaningful way.

\section{The encounter with the science classroom}

Several studies indicate that students' encounter with the science classroom constitutes a meeting with a new social practice. In this practice, students speak, think and act in a manner that differs from their everyday lives (Kelly 2011). Already familiar words are transformed and used in a new way (Wickman 2013). Therefore, the students must understand how words, which may connote different meanings in different discourses, are used in specific situations to make meaning of the science content (Serder and Jakobsson 2016). Another example is the use of a more subject-specific language, which implies that the verbal and written language becomes more formal and abstract. To participate in this new practice, the students must partake and learn new language games (Wittgenstein 1967), "the new language-games of science" (Wickman 2013, p. 124). This implies that the students have to learn how to use the language of science and understand how it is used in a science classroom. The subject-specific language in science describes the content in a functional manner (Halliday and Martin 1993) and is important "for accurately conveying the specialized knowledge of science" (Fang 2006, p. 494). Grammatical functional technology (such as subject-specific use of nominalizations 
and passive forms) is used to express the science subject matter in a functional way (Halliday 1998). Another functional manner in scientific language is the use of descriptive, clarifying and interconnecting words and phrases that create meaning through realizing semantic relationships between objects and phenomena (Fang 2005). This is central in all meaning-making processes because scientific concepts often acquire meaning by being taxonomically related to each other through semantic relations into larger thematic patterns (Lemke 1990).

When language and subject constitute one another (Nygård Larsson 2011), the prerequisite for developing scientific knowledge also is appropriated by the subject-specific language. Lay Hoon Seah, David John Clarke and Christina Eugene Hart (2014) argue for the importance of students developing an understanding of how to use the subject-specific language. This means not only understanding the meaning and the nature of words and concepts, but also the conditions and circumstances of when and how to use them and how to semantically relate the words to create meaning. Furthermore, the students must understand the differences between various ways of using and relating words and concepts to each other in verbal and written language and in everyday language and school language.

\section{The science classroom as a meeting space}

Research shows the importance of students' negotiating and transforming the science content in relation to prior experience in science learning, and students' empowerment in science education (Tan et al. 2012). Carolyn Wallace (2004) thinks this is feasible, if a space between everyday discourse and academic discourse is created in science classrooms, in which linkages among various discourses and practices can occur in teaching and learning contexts (Quigley 2011). Kris Gutiérrez, Betsy Rymes and Joanne Larson (1995) defines this as third space, in which students can relate and integrate discourses from their everyday life with the new, unfamiliar science discourse (Kamberelis and Wehunt 2012). Interweaving science content with students' experience of their lives outside of school, and their cultural and linguistic backgrounds, enriches the science experience because the relevance of their experiences and lives is foregrounded (Tan et al. 2012).

\section{Meeting place for discursive languages}

Several researchers emphasize third space from a language perspective as a hybrid (Bakhtin 1981) learning space in science education (Jakobsson, Mäkitalo and Säljö 2009). When students relate the subject matter to everyday experiences in their continuous reconstruction (Dewey 1902) of the science content, they move between their everyday language and the school science language. Accordingly, there is a continuum space between the two endpoints; a third space in which various discursive languages come together and the meaning of words and expressions are negotiated. This use of merged language has different terms, such as double talk (Brown and Spang 2008) and interlanguage (Olander 2010). The ability to use an everyday language in science classrooms allows students to engage in a "practice of generating and creating scientific explanations in their own voice" (Brown, Cooks and Cross 2016, p. 454) and has should be used as a resource in appropriating scientific language (Olander 2010). This allows the third space to become an important place for appropriating scientific language and relating the scientific content to prior experience (Wallace 2004), not the least in multilingual science classrooms. 


\section{Meeting place for both discursive and national languages}

For the third space to be a place for linkages among various discourses and practices in multilingual science classrooms, the main condition is that participants can use a language that makes this possible, such as both national and discursive languages. García and Wei (2014) use the term translanguaging to describe such a practice: "For us, translanguaging refers to a new language practice that make visible the complexity of language exchanges among people with different histories and releases histories and understandings that had been buried within fixed language identities constrained by nation-states" (p. 21). In other words, the students must use a language that constitutes their prior experience (such as personal experiences or familiar ideas or objects) to make connection to the new science discourse. The consequence of this is that the language use in a multilingual science classroom must be extended to even include a merging of national languages. In this way, a translanguaging practice (Wei 2011) can be compared to a third space in multilingual science classrooms. A translanguaging practice is a space for teaching and learning through multimodal interactions and semiotic inter-relationships (such as oral and written language, signs, gestures and symbols). According to Karlsson et al. (2018), a translanguaging science classroom constitutes a third space in science education, in which students and teachers can use all available languages resources in a pragmatic and functional way to relate the science subject matter to prior experience in all meaning-making processes. In this way, third spaces in science education can be important for continuity in science learning for those students who have limited opportunities to understand and express themselves in the language of instruction.

Furthermore, theories of translanguaging assume that multilingualism is the norm (García et al. 2014). Therefore, instead of talking about first and second languages, translanguaging theories derived from the language practice of multilingual people are the norm: "Translanguaging is multiple discursive practices, in which bilingual engage in order to make sense of their bilingual world" (García et al. 2014, p. 22). In this article, we use the terms first language and second language only to clarify in which ways students use Arabic and Swedish in oral meaning-making conversations in the science classroom.

\section{Verbal language usage in a translanguaging science classroom}

If students are encouraged and allowed to use all available language resources in science classrooms, it empowers them in several ways. Such an argument is supported by several other studies. Alma Stevenson (2013) shows that bilingual Latino students use their linguistic resources in both Spanish and English to seek clarification "to receive a lecture, when they were uncertain regarding experiment directions in the laboratory or the names of tools or artifacts, and during the introduction of new scientific concepts" (p. 981-982). In a South African study, Audrey Msimanga and Anthony Lelliott (2014) show that students' use of their home language during small group discussions in a Grade 10 Chemistry class enriches the science learning experience and facilitates conceptual understanding.

More specific, micro-level studies reveal how students use all their language resources in meaning-making situations in science classrooms when there is an opportunity for this. In a study of a TSC, Karlsson et al. (2016) found that multilingual students move in linguistic loops between discursive and national languages in their conversations about the scientific content. The students commonly use their first language (Arabic) when moving 
toward an everyday discourse and use their second language (Swedish) when approaching the scientific discourse. This implies that the students' discursive mobility (Nygård Larsson 2011), their ability to move between discourses, increases when they use both Swedish and Arabic. Moreover, analyses show how the students often use both Swedish and Arabic to clarify semantic relationships between scientific words and concepts in this practice (Karlsson et al. 2018). The students commonly express the subject-specific words in Swedish, while the descriptive, clarifying, interconnecting words and phrases describing the semantic relationships often are expressed in Arabic. In this way, both Arabic and Swedish become linguistic and cognitive tools when students learn science. Furthermore, the students' opportunity to develop an understanding of the semantic relationships between concepts increases, as well as how they relate in larger thematic patterns (Lemke 1990), increases.

Another aspect, included in the language games of science, is the ability to argue, discuss and explain ideas (Lemke 1990). In a Swedish study, Ünsal and colleagues (2017) examine how multilingual students use Swedish and Turkish in meaning-making situations in a science classroom. The study shows that students with limited possibility to express themselves in the language of instruction only participate in whole class conversations if the conversations follows an IRE pattern (initiative-response-evaluation) (Mehan 1979), in which only short answers in the form of reproducing factual knowledge are required. However, if the whole class conversation involves more explanatory and extended dialogues, these students have little access to argue, discuss and explain their ideas. On the other hand, when the activity switches to small group work and the students can use both Turkish and Swedish, their verbal contributions become more advanced. In this way, the group work gives the students an opportunity to participate in arguments and discussions in the science classroom.

Another way to achieve greater opportunity for multilingual students to use all their language resources is with multilingual study guidance (Reath Warren 2016). In Sweden, multilingual study guidance implies that a mother tongue teacher supports the students to reach the learning goals in the curriculum by using all available language resources. Both the mother tongue teachers and the students move between the mother tongue and the language of instruction during the guidance. Reath Warren (2016) found several functions of multilingual study guidance for recently arrived students' learning in Sweden. The mother tongue teacher helps the students clarify the meaning of words and phrases by translating them into another language. The teacher also discusses and explains the subject matter and the school's expectations for the students. Moreover, the guidance involves meta-linguistic awareness about the Swedish language and sociocultural awareness (such as clarifying social and cultural similarities and differences). The aim of multilingual study guidance is not to make the students monolingual. Rather, the aim is that the students' whole linguistic repertoires should be used and developed and be a resource in all meaning-making situations. This is in line with Ofelia García and Naomi Kano's (2014) research about translanguaging, which shows that emergent bilinguals do not acquire a separate additional language. Instead, two or more languages merge and are used together in a pragmatic and functional manner through complex, dynamic multilingual practices. 


\section{The aim of the study}

The aim of this study is to explore and clarify how multilingual students use their first and second languages (Arabic and Swedish) as resources in authentic, meaning-making situations in a TSC. Furthermore, the study investigates how the students' usage of these languages may affect continuity of science learning. More specific questions are:

- How can a translanguaging practice affect the students' ability to appropriate the ways of speaking, thinking and acting in a multilingual science classroom, and what possible obstacles for science learning may arise?

- How can a translanguaging practice affect the continuity of science learning in multilingual classroom activities?

\section{Context, methods and analysis}

\section{Setting, context and participants}

The study was conducted at a primary school located in a multicultural neighborhood in southern Sweden under 3 years and followed a class from grades 4 to 6 . This class was special because it had received bilingual education in Swedish and Arabic from grade 1 to 3 , which meant that the students used both languages as a resource in all classroom meaning-making situations. When the class started grade 4, the availability of Arabic was limited, such that all ordinary instructions were only in Swedish. This means that the classroom teacher designed and had all the instructions in Swedish, while the mother tongue teacher was involved by supporting the individual students who needed support in the second language in the form of multilingual study guidance. These students received guidance in about half of all of the science lessons. In the project, however, all students were encouraged to continue using both Arabic and Swedish as a resource in conversations with their classmates in all classes. In this way, almost all science lessons may be understood as a translanguaging practice (García et al. 2014). The class was taught by two teachers: Louise taught social sciences and Swedish, and Lotta taught natural science and mathematics. The mother tongue teacher, Fatima, who was educated as a language teacher in her native country, supported in the form of multilingual study guidance. The mother tongue teachers' education is highly variable; some of the mother tongue teachers are trained teachers, while others lack teacher training and then work primarily as interpreters/translators. Furthermore, one of the students, who needed special assistance, got help from an assistant, Maria. The class consisted of approximately the same group of 20 students throughout the study duration. However, three students, newly arrived in Sweden, started the class during the data collection. These three students (Montazar, Haydar and Halima) all spoke Arabic as their mother tongue.

The examples that we use to illustrate how the students' use their first and second languages can affect their ability to appropriate the ways of speaking, thinking and acting in a multilingual science classroom, and the continuity of science learning in multilingual classroom activities is taken from two science lessons (May 12-13, 2014). These two lessons were part of a work area aimed at developing knowledge about plant species in the surrounding environment; the name of some common species; and how these can be identified, sorted, grouped and determined. Anna (specialization in Natural Science and 
Mathematics) had introduced the subject matter a week before by showing a film describing the subject area, and during these two lessons, the students were to read a text about the different types of forests in Sweden (coniferous, deciduous and mixed coniferous) and their specific species of trees ("Appendix 1"). Since Anna was not in school that week, the lessons were conducted by Louise (specialization in Social Science and Swedish). She worked consciously and distinctly with the language in all subjects. For example, she taught students different reading strategies. In the second lesson (May 13, 2014), the class also got multilingual study guidance from Fatima.

\section{Methods, considerations and data collection}

In this study, we explore how multilingual students' use of their first and second languages in authentic oral meaning-making situations may affect their appropriation of the ways of speaking, thinking and acting, as well as the continuity of science learning. Accordingly, our focus is foremost on the use of first and second language, although we are aware that verbal language only constitutes a part of all the languages resources used to create meaning in science classrooms (Jakobson and Axelsson 2017). There is a problem with separating different modes, as they often interact and are used together. Therefore, the prerequisites for visualizing and understanding the authentic use of first and second languages and its consequences for continuity in science learning are to clarify how they are used in parallel, and conjunction, with other language resources, and above all, understand the situation in which they are used. For this reason, we use an ethnographic data collection and research design (e.g., Marcus 1995). By using this method, it also becomes possible to implement nonparticipant observation, which is very important for capturing the authentic language used in meaning-making situations (Bryman 2015). To support this work, field notes and different types of texts and other teaching materials were collected. In addition, four video cameras and four audio recorders were used to record all the lessons. This was an important tool in data collection to visualize and try to understand how the participants' authentic language use may affect the continuity of science learning in this TSC.

The students were seated around four tables in the classroom, so the four cameras were directed toward these four tables to capture the students' conversations. Unfortunately, it was sometimes hard to hear what the students were saying in the video recordings, since their voices overlapped each other. Therefore, the audio recordings constituted a very important complement. The use of both the audio and video recordings increased the credibility and minimized possible bias (Mondada 2006). In the beginning of the study, both students and teachers spoke with the observer in the classroom and turned to the cameras to get in the picture. As the activities started and the participants became more used to the visits, both teachers and students paid less attention to the cameras and the observer. This also increased the authenticity.

Furthermore, to deepen our understanding of the students' language use in this TSC, we conducted individual structured conversations (each about $20 \mathrm{~min}$ ) once a year in an adjoining room with the students who recently had arrived in Sweden: Ali (three times), Montazar (two times), Haydar (once) and Halima (once). The conversations were about the students' prior experience of school science and what they thought about the science education in Sweden. The mother tongue teacher (Fatima) interpreted and participated in these conversations. They were audio and video recorded because they were subsequently translated from Arabic into Swedish and also to increase the credibility.

A total of $117 \mathrm{~h}$ of student and teacher interactions in the classroom were recorded (see Fig. 1) and $2.5 \mathrm{~h}$ of conversations with the students who had newly arrived in Sweden. 


\begin{tabular}{|c|c|c|c|l|}
\hline Grade & Lessons & $\begin{array}{c}\text { Number of } \\
\text { audio } \\
\text { players }\end{array}$ & $\begin{array}{l}\text { Number } \\
\text { of video } \\
\text { cameras }\end{array}$ & $\begin{array}{l}\text { Total } \\
\text { recorded } \\
\text { movies/film }\end{array}$ \\
\hline $\mathbf{4}$ & 11 & 3 & 3 & $3 \times 11 \mathrm{~h}=33 \mathrm{~h}$ \\
\hline $\mathbf{5}$ & 11 & 4 & 4 & $4 \times 11 \mathrm{~h}=44 \mathrm{~h}$ \\
\hline $\mathbf{6}$ & 10 & 4 & 4 & $4 \times 10 \mathrm{~h}=40 \mathrm{~h}$ \\
\hline & & & & Total $=\mathbf{1 1 7 h}$ \\
\hline
\end{tabular}

Fig. 1 Video and audio recordings from the science lessons

The data collection addressed the ethical considerations and the permissions required to film students in a school context. The teacher and the students and their parents/guardians were all informed about the study, and that participation was voluntary.

\section{The analytic procedure}

In this article, we assume that learning takes place through interaction (Jakobsson 2012) and transaction (Östman and Wickman 2014) in dialogical processes (Linell 2009). In the dialogues, voices (Bakhtin 1986) from prior situations "speak", and in this way, past experiences are linked with current experience, which together with the context constitute the ongoing flow of experience (Dewey 1938/1997). In these processes, the language is the most used tool for communication (Dewey 1925/1995): "As to be a tool, or to be used as means for consequences, is to have and to endow with meaning, language, being the tool of tools, is the cherishing mother of all significance" (p. 186). The language carries historical and cultural significance (Säljö 2010). Simultaneously, the meaning of words and concepts depends on the language game in which they are used (Wittgenstein 1967). In this way, the language has at least two dimensions - a mediated meaning (the language's historical and cultural significance) and a situational language use-which are constantly interacting with each other. As a result, the language is both a mediating tool for the knowledge/experience that constitutes the discourse (Säljö 2010) and a pragmatic, functional action for continuity and transformation (Wittgenstein 1967). This means that language is not only verbal language. It is also included in all actions, images and objects that in some way express meaning and create significance in situations (Säljö 2010). Therefore, the participants' speech acts in a science classroom also include body language and gestures (Ünsal, Jakobson, Wickman and Molander 2018) and how the participants use different physical artifacts to express meaning (Lidar, Almqvist and Östman 2010). Using all these different modes of language (Danielsson 2016), continuity in science learning in classrooms activities can be created (Wickman 2013). In this way, all kinds of language become the most important tool in all meaning-making situations in a science classroom.

We assume that learning takes place through interactions and transactions between individuals and individuals and their environment (Hamza and Wickman 2009). In these interactions and transactions, contexts and cognitive, aesthetic and moral learning are intertwined in each other (Wickman 2013), so learning involves many dimensions of both situational and continuous aspects (Roth and Jornet 2014). Therefore, to analyze the consequences of using both first and second languages in a TSC for continuity in science learning, we must take into account both the role of the situation and "the role of experiences within a sociocultural perspective on learning” (Lidar et al. 2010, p. 690). 
In this work, the practical epistemologies analysis (PEA) (Wickman and Östman 2002) analytic model proved to be a useful tool (Kelly, McDonald and Wickman 2012). PEA is based on a sociocultural epistemology, pragmatism and the later work of Wittgenstein and is used to study students' learning in science. PEA's focus is own students' actions, including speech, when participating in different activities in science classrooms. PEA is grounded in four categories: encounters, stand fast, gaps and relations. Encounters involve finding other experiences in the situation, in the form of utterances, texts, physical objects and pictures. Stand fast in an encounter implies that the meaning of a word or an object is obvious for the participants, with respect to this specific situation, so is not questioned. When something does not stand fast, there is a gap, so the participants strive to create relations to what stands fast. If the participants succeed in creating relations, the gap is filled, and there is continuity between past and present experiences in the conversation/activity. If not, the gap lingers and the conversation/activity may change direction. In this way, PEA helps clarify the participants' use of first and second languages to fill gaps that occurs in the encounter with the new science discourse and how this affects the continuity of learning in the multilingual classroom activities.

Moreover, it became possible with PEA to divide the conversations/activities into different steps (Piqueras, Hamza and Edvall 2008), in which the gaps identify the shifts between the steps. Accordingly, linger gaps often defined a change of direction in the conversations/ activities, which was an important tool for visualizing and analyzing the use of first and second languages in the movements through and between the different steps, as well as the consequences of this. In turn, this revealed and clarified the change of direction in the conversation/activity, or the reasons why filled or linger gaps arose, and the consequences of these for the continuity of science learning.

In the first phase of the analytic procedure, all the collected data were carefully reviewed, and the content-related situations, in which the participants used both first and second languages in interactions, were selected for further analysis (approximately $10 \mathrm{~h}$ ). Both conversations between students and conversations between teachers and students were of interest. In the second phase, the participants' use of first and second languages was analyzed, based on results from previous analyses: moving in linguistic loops when relating the scientific content to prior experience (Karlsson et al. 2016), and realizing meaning semantically (Karlsson et al. 2018). In the third phase, we used PEA to clarify and understand how the participants' use of first and second languages may affect their ability to appropriate the ways of speaking, thinking and acting in the science classroom and how this can affect the continuity in the classroom activities. Finally, in the fourth phase, we started from the gaps that occurred in the conversations/activities and tried to understand why gaps occurred; how the students created relations with what stood fast to fill the gaps; reasons for lingering gaps; and how this affected the direction of the conversation/activities and the continuity of students' science learning. The three conversation sequences selected in the result section are typical of the total data material in the sense that conversations like these occur commonly among all students.

The transcription was performed with an Arabic-speaking translator and reviewed by one teacher whose mother tongue is Arabic. The recordings were transcribed into Swedish and Arabic and then translated into English. The speakers' original statements in Swedish or Arabic are available in "Appendix 2". The statements in which both Swedish and Arabic were used are printed twice (first in Arabic and English, and then in English only). For the reader, the last column in the excerpts provides a contextual description of the situation. 


\section{Results}

In this, we explore and describe how the multilingual students' use of their first and second languages may affect their ability to appropriate ways of speaking, thinking and acting in a multilingual science classroom and how this can affect the continuity of science learning in classroom activities. To illustrate this, three typical conversation sequences from grade 5 (Excerpts 1-3) and one conversation with Halima from grade 6 (Excerpt 4) are chosen.

\section{Ways of speaking, thinking and acting in a translanguaging science classroom}

Louise (the Swedish and social sciences teacher) explains that students will read a text about three different types of forests in Sweden (coniferous, deciduous, and mixed coniferous) and their specific species of trees. Before they start reading the text, the students are invited to relate the content of the text to their prior experiences and talk about what they think the text will be about. Practically, the students individually write down what they think the text will be about (their prior experience with the subject matter) and then read aloud in small groups what they have written. Each group discusses what they think the text can be about and write it down. Finally, they read it aloud to the whole class. Louise gives the instructions in Swedish, and then, she asks one of the students to also explain the instructions in Arabic. In Excerpt 1 (Fig. 2), Adnan, Amir, Halima, Roshalat, Furkan, Rajaa and Maria (the assistant to one of the students) share their thoughts. Adnan is the group leader and manages the conversation. After Amir, it is Halima's turn (at this time, Halima has been in Sweden for about four months).

Louise explains to the students that they should write down their prior experience with the subject matter and then read and discuss this in small groups. Halima does not write anything down, either in Swedish or Arabic. This is probably why Adnan invites Halima to express her thoughts in Arabic (1). By doing this, Adnan introduces the possibility of using Arabic in this science classroom. He expresses this by doing it himself and explaining to Halima in Arabic: if you have it in Arabic/say it (1). This is an example of Adnan's repeated attempts during the conversation to get Halima to share her thoughts and prior experiences with the group $(10,12,13,14)$. Adnan's attempts to encourage Halima to express her thoughts can be interpreted as an implicit explanation of what is expected of her in this context and the importance of all students sharing their prior experiences on the subject matter. Another example of this is when Adnan does not force or stress Halima to answer, but instead gives her time to think (4). By doing this, Adnan indirectly states that there will be other opportunities for her to speak. Adnan is the group leader and, through his actions, he clarifies some important rules in the language game that they play in this science classroom. The students are encouraged to express themselves in Arabic and create relationships between the two languages, and its specific contexts, which creates continuity in learning. In addition, all students are expected to share their thoughts and prior experiences with the class. We interpret this as an example of a translanguaging practice that evolved due the use of several language resources and the socialization of students who have been in the class for a certain length of time. This practice makes it possible for Halima to ask Furkan in Arabic what is expected of her (6) and for Furkan to explain the prerequisites for the task in Arabic $(7,8)$. Furthermore, this practice creates conditions 


\begin{tabular}{|c|c|c|c|c|}
\hline Turn & Person & Transcription & Arabic & Contextual description \\
\hline 1. & Adnan: & $\begin{array}{l}\text { low andek bl arabi/betroji } \\
\text { (if you have it in Arabic/say it) }\end{array}$ & بالعربي قوله اذله & Adnan explains to Halima. \\
\hline 2. & Halima: & & & Halima nods. \\
\hline 3. & Furkan: & $\begin{array}{l}\text { oli shi/lazem etoli shi ala al shajara } \\
\text { (say something/you have to say something about } \\
\text { the tree) }\end{array}$ & يجب أن تقوليء شيء & $\begin{array}{l}\text { Furkan also turns to } \\
\text { Halima and explains for } \\
\text { her in Arabic. }\end{array}$ \\
\hline 4. & Adnan: & $\begin{array}{l}\text { bedek takhde waket o tfakre shwai } \\
\text { (you can take your time and think a little [about } \\
\text { it]) }\end{array}$ & يمكناك أخذ وقتا & $\begin{array}{l}\text { Adnan makes a circular } \\
\text { motion with his hand that } \\
\text { shows that the others in } \\
\text { the group can answer first. }\end{array}$ \\
\hline 5. & Halima: & & & Halima nods. \\
\hline $\begin{array}{l}{[30: 46-} \\
33: 09]\end{array}$ & & $(\ldots)$ & & $\begin{array}{l}\text { Adnan gives the word to } \\
\text { the others, one by one. }\end{array}$ \\
\hline 6. & Halima: & $\begin{array}{l}\text { Furkan kef yaani } \\
\text { (Furkan how do you mean) }\end{array}$ & فرقان كيف & $\begin{array}{l}\text { After a while, Halima } \\
\text { leans forward to Furkan } \\
\text { and ask her in Arabic what } \\
\text { the task is about. }\end{array}$ \\
\hline 7. & Furkan: & $\begin{array}{l}\text { rah naqraa waraqa an al alshagara } \\
\text { (we will read a paper about the tree) }\end{array}$ & سوفة الثجرة عنر & $\begin{array}{l}\text { Furkan explains in Arabic } \\
\text { that they will read a text } \\
\text { about trees. }\end{array}$ \\
\hline 8. & Furkan: & $\begin{array}{l}\text { yaani lazem enti etfakri kel shi eli fiha al } \\
\text { shagara o wen betkon } \\
\text { (that means that you have to think about } \\
\text { everything about tree and where is the tree) }\end{array}$ & يجب ان تفكري انتي & $\begin{array}{l}\text { She then explains to } \\
\text { Halima in Arabic what she } \\
\text { is expected to do. }\end{array}$ \\
\hline & & & تكون & \\
\hline 9. & Halima: & & & Halima nods. \\
\hline $\begin{array}{l}{[33: 25-} \\
34: 01]\end{array}$ & & $(\ldots)$ & & $\begin{array}{l}\text { All the other students } \\
\text { share their thoughts with } \\
\text { the group. }\end{array}$ \\
\hline 10. & Adnan: & $\begin{array}{l}\text { bedek etgoli she } \\
\text { (do you want to say something) }\end{array}$ & تل تل تريدي شيء & $\begin{array}{l}\text { Adnan asks Halima once } \\
\text { again, if she wants to say } \\
\text { something. }\end{array}$ \\
\hline 11. & Halima: & $\begin{array}{l}\text { la khalas laa } \\
\text { (no it is enough) }\end{array}$ & لا هذا يكفي & $\begin{array}{l}\text { Halima looks shy and } \\
\text { leans over the table, when } \\
\text { she answers. }\end{array}$ \\
\hline 12. & Adnan: & $\begin{array}{l}\text { lazem yani ahsan taaraf al moalema men ali } \\
\text { haka w men eli ma haka } \\
\text { (you have to }[\mathrm{I}] \text { mean that you have to make } \\
\text { sure that the teachers know who has talked and } \\
\text { who has not talked) }\end{array}$ & تيجب يعني المعلمة & $\begin{array}{l}\text { Adnan explains to Halima } \\
\text { that she had to say } \\
\text { something, so the teacher } \\
\text { will know that Halima had } \\
\text { said something about the } \\
\text { subject matter. }\end{array}$ \\
\hline $\begin{array}{l}{[34: 13-} \\
34: 25]\end{array}$ & & $(\ldots)$ & & $\begin{array}{l}\text { Halima does not answer } \\
\text { and leans forward again. }\end{array}$ \\
\hline 13. & Adnan: & $\begin{array}{l}\text { goli mathHanan gadesh al shagra omrha goli bs } \\
\text { haik } \\
\text { (for example you can say how old the tree is say } \\
\text { only that) }\end{array}$ & 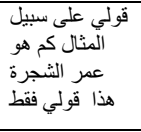 & $\begin{array}{l}\text { Adnan urges Halima to } \\
\text { say something about the } \\
\text { subject matter. Halima } \\
\text { does not answer. }\end{array}$ \\
\hline $\begin{array}{l}{[34: 29-} \\
38: 36]\end{array}$ & & $(\ldots)$ & & $\begin{array}{l}\text { The group writes a } \\
\text { summary. }\end{array}$ \\
\hline 14. & Adnan: & Halima do you have anything more & & $\begin{array}{l}\text { Adnan once again asks } \\
\text { Halima if she wants to add } \\
\text { something, this time in } \\
\text { Swedish. }\end{array}$ \\
\hline 15. & Halima: & $\begin{array}{l}\text { wen tenmo al shagara } \\
\text { (where does the tree grow) }\end{array}$ & أين تنموة & $\begin{array}{l}\text { Halima nods and answers } \\
\text { in Arabic. }\end{array}$ \\
\hline
\end{tabular}

Fig. 2 Excerpt 1: 140512D1 [30:22-38:43]; Adnan, Amir, Halima, Roshalat, Furkan, Rajaa and Maria (the assistant for one of the students) 
that make it possible for Adnan to explain to Halima the importance of sharing her prior experience with her classmates and the teachers $(12,13)$. This finally leads Halima to take the opportunity to express that she thinks that the text may be about where trees grow (15). The peer support in Arabic helps Halima to appropriate how to behave, act and express herself in this specific practice. In the analysis, we can see that Halima gradually understands this part of the language game, namely the importance of expressing and sharing her prior experience, and that all students are encouraged to use all language resources that makes this possible.

We define this as an example of a TSC, a practice in which students can relate and integrate discourses and experiences from their everyday life with the new, unfamiliar science discourse, in a language that make this possible. In this way, TSC can be compared with third space, which is interpreted as a negotiation space in which students can relate everyday experiences and expressions with the new experiences and expressions they encounter in school contexts. Consequently, students in multilingual classrooms, whose everyday language is other than that used for instruction, also must use their everyday language when negotiating the subject matter in third space. Accordingly, we also find that the third space constitutes a meeting place between students' different language resources and national languages. By using a language that Halima understands (Arabic), it becomes possible for Adnan, Furkan and Halima to create relations when gaps occur in Halima's encounter with this new practice. In turn, the filled gaps may contribute to continuity in the multilingual classroom activities, which increases Halima's ability to appropriate ways of speaking, thinking and acting in this practice, even though she at this time still has limited access to the language of instruction (Swedish). The teacher's organization of the lesson is another important factor that contributes to shaping this practice/space. Through small group activities, in which all students are expected to share their prior experiences, students such as Halima get the opportunity to express and relate the subject matter to their prior experiences, such as prior schooling in other countries. In this way, we see increased opportunities for students to use their prior experience, even for those who do not have full access to the language of instruction. This increases the likelihood of continuity in science learning, based on students' prior experiences, and students being empowered in science education.

\section{What is barrskog (coniferous forest)?}

In the next excerpt (Fig. 3), we follow the same group of students when they read together and discuss the text about three different types of forests in Sweden (coniferous forest, deciduous forest and mixed coniferous forests). Before the students read the text, Louise explains some reading strategies that they can use. One strategy is to divide compound words and find out which each part of the word means. This can be a useful strategy, since it is common to put individual words together to make them compound. For example, barrskog is the word for a coniferous forest, which is literally translated as needles-forest. The Swedish word for a deciduous forest, on the other hand, is lövskog, literally translated as leaves-forest. In this example, it is easy to deduce that the word skog would likely mean forest in Swedish. In the first paragraph of the excerpt below, the students encounter the word "barrskog" (coniferous forest), and Furkan explains to Halima that this is a kind of name for a type of forest and states that it is hard to explain. 


\begin{tabular}{|c|c|c|c|c|}
\hline Turn & Person & Transcription & Arabic & Contextual description \\
\hline 16. & Furkan: & $\begin{array}{l}\text { fi shagara/yanni endaha hai al leaves/bs } \\
\text { (there is tree/that means that they have leaves/but) }\end{array}$ & هذه في شني عندها: & $\begin{array}{l}\text { Furkan explains that some } \\
\text { trees have leaves. She uses } \\
\text { the Swedish word for } \\
\text { leaves. }\end{array}$ \\
\hline 17. & Adnan: & $\begin{array}{l}\text { al warak } \\
\text { (leaves) }\end{array}$ & الأوراق & $\begin{array}{l}\text { Adnan adds the Arabic } \\
\text { word for leaves, in } \\
\text { Palestinian dialect. }\end{array}$ \\
\hline 18. & Furkan: & $\begin{array}{l}\text { bs al warak bs bl al needles/fi menon andon hard } \\
\text { sticks haiek hard sticks/fahmti... } \\
\text { (only leaves only with needles/some of them have } \\
\text { hard sticks hard sticks like this hard sticks/have you } \\
\text { understood...) }\end{array}$ & 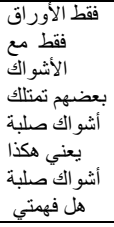 & $\begin{array}{l}\text { Furkan explains that some } \\
\text { trees have needles. While } \\
\text { she explains, she grabs } \\
\text { one of the leaves on the } \\
\text { plastic potted plant } \\
\text { standing at the table in } \\
\text { front of them. }\end{array}$ \\
\hline 19. & Halima: & & & Halima gives no response. \\
\hline 20. & Adnan: & $\begin{array}{l}\text {...al assyat al qauia... } \\
(\ldots \text { small hard sticks...) }\end{array}$ & العصيات & $\begin{array}{l}\text { Adnan tries to explain by } \\
\text { using a word "small hard", } \\
\text { in standard Arabic. }\end{array}$ \\
\hline 21. & Maria: & ...does she know what a Christmas tree is & & $\begin{array}{l}\text { The assistant Maria asks } \\
\text { Furkan if Halima knows } \\
\text { what a Christmas tree is. }\end{array}$ \\
\hline
\end{tabular}

Fig. 3 Excerpt 2: 140512D1 [1:01:34-1:01:54]; Adnan, Amir, Halima, Roshalat, Furkan, Rajaa and Maria

In this excerpt, Furkan uses Swedish to express the subject-related words: leaves (16) and: needles (18), while describing and explaining these words in Arabic. Adnan adds the Arabic word, al warak (leaves) (17), but they do not translate the Swedish word barr (needles) into Arabic. Instead, Furkan tries to explain what needles are by using the phrase hard sticks in both Swedish: hard sticks (18) and Arabic: fi menon andon (some of them have hard sticks) (18). Adnan uses the Arabic phrase: al assyat al qauia (small hard sticks) (20). Furkan also grabs some of the leaves on the plastic potted plant on the table to concretize what she means (18). Despite this use of different available languages resources, Furkan expresses that it is hard to explain the meaning of the word. One possible explanation is that Furkan and Adnan do not know a corresponding word for needles in Arabic. Another explanation may be that the Swedish word barr (needles) is expressed in Arabic with both the word needles and the word coniferous. Therefore, the strategy of dividing compound words becomes problematic in this situation. The word needles is removed from its semantic relationship with the forest. However, without the word forest, there is a risk that the language game about different types of forests will take another direction. This happens when Halima does not seem to understand what they mean (19). So Maria tries to explain what needles are by relating them to a completely different context of Christmas tree (21). However, Halima has probably never seen a Christmas tree because at this time she has been in Sweden for only four months. Accordingly, to continue the language game about different types of forests, and explain and understand what a coniferous forest is, would have been more beneficial if the compound word barrskog (coniferous forest) had not been divided, so had not omitted the significant word forest and its semantic relation to the word tree and different types of forests.

In this translanguaging practice, the students use different resources, including both Swedish and Arabic languages, and a plastic potted plant to explain and contextualize the word needles. However, the question remains as to whether or not it is possible for Halima and the other students to develop any deeper knowledge about the words in this situation. Furthermore, it is still unclear if Halima understands all the meaning of the concept coniferous forest, what needles are in this context, or how this is related to Christmas trees. In 
other words, an obvious gap occurs when the students encounter the Swedish word for coniferous forest in the text. The students try to fill the gap by relating needles to leaves $(16,18)$, but the gap lingers. The consequence is that the conversation moves from the language games of science (Wickman 2013) to a completely different language game, in which Maria tries to explain what needles are by referring to Christmas trees (21). Maria's and Halima's everyday experiences probably differ, so it is difficult to explain what a coniferous forest is by relating to an everyday experience that they may not share. Instead, it might have been easier to explain and understand what a coniferous forest is, if there had been multimodal resources such as a figure in the text that showed the semantic relation between the different types of forests and illustrated some of the species of trees that grow in these forests. This multimodal resource might have filled the gap and helped the students facilitating continuity in the language games of science. For example, this could have led to a question of why different species of trees grow in different environments. Even a close-up photograph of a leaf and a needle could probably be a multimodal support for the students and might have raised questions from the students as to why needles and leaves look different and why much of Sweden has coniferous forests. However, the gap is not filled, which causes the language game to turn away from science, and instead a Swedish cultural tradition is involved.

\section{The translation of a written text in Swedish into an oral text in Arabic}

Excerpt 3 (Fig. 4), from the following lesson (May 13, 2014), shows how the mother tongue teacher (Fatima), together with Zein, Nour, Haydar, Hanan and Halima, reads and interprets the text about different types of forests in Sweden. They sit in a small room adjacent to the classroom. Haydar (a newly arrived student) reads the first paragraph in Swedish, while Fatima explains some of the words from the text (such as half of and consist of) in Arabic. Hanan wonders if Halima understands, but Halima does not answer. Fatima then starts to explain the text in Arabic.

Both Haydar and Halima have recently arrived in Sweden, and Fatima supports them by translating the text. First, she reads a sentence, and then, she translates and formulates the content of the sentence using her own words. In doing this, she transforms the written, academic discourse in the text into an everyday discourse in Arabic. For example, consists of lots of forest (23) in Swedish is transformed to has lots of trees (23) in Arabic. Another example is when Fatima translates a little more than half of the Swedish land area consist of forest (24) in Swedish to about half of Sweden is full of trees (24) in Arabic. This also transforms the meaning of the subject content (forests is transformed to full of trees). Accordingly, the movement between different national and discursive languages [the movement in linguistic loops (Karlsson et al. 2016)] contributes to a gap, which Zein's response suggests: bl ashgar (of trees) (25). The Arabic word ghabe (forest), which probably could have been a useful linguistic tool in this language game, is never used. Fatima repeats the word forest several times in Swedish $(23,24,26,28)$, but never uses ghabe. Why this word is not used is uncertain. Fatima may assume that not every student knows what a forest is and explains this at the same time as she translates the word into Arabic. However, this simplification creates a linger gap, as seen by Hanan's statement in Arabic: we have three different kinds of trees in [Sweden] (29). In this way, the linger gap interferes with the multilingual classroom activity, which probably has consequences for students' learning and language use in this situation. 


\begin{tabular}{|c|c|c|c|c|}
\hline Turn & Person & Transcription & Arabic & Contextual description \\
\hline 22. & Fatima: & $\begin{array}{l}\text { okej bshrahlekom jaha bl arabi w baaden } \\
\text { btshofonha kef tehkonha bl swedi } \\
\text { (okej I will explain it to you in Arabic then you } \\
\text { will see how to say it in Swedish) }\end{array}$ & 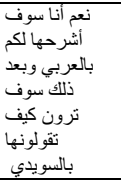 & $\begin{array}{l}\text { Fatima explains for the } \\
\text { students. }\end{array}$ \\
\hline 23. & Fatima: & $\begin{array}{l}\text { consists of lots of forest yaani beniesh fi balad } \\
\text { mantaqa fiha shagar keter } \\
\text { (consists of lots of forest we live in a country } \\
\text { landscape which has lots of trees) }\end{array}$ & 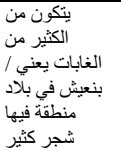 & $\begin{array}{l}\text { First Fatima reads the text, } \\
\text { then she translates what she } \\
\text { has read into Arabic with her } \\
\text { own words. }\end{array}$ \\
\hline 24. & Fatima: & $\begin{array}{l}\text { a little more than half of the Swedish land area } \\
\text { consist of forest yaani taqriban noss al swed } \\
\text { malian bl ashgar } \\
\text { (a little more than half of the Swedish land area } \\
\text { consist of forest that means that about half of } \\
\text { Sweden is full of trees) }\end{array}$ & 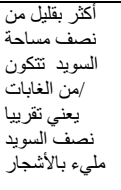 & $\begin{array}{l}\text { Fatima reads, and explains the } \\
\text { content of the text. }\end{array}$ \\
\hline 25. & Zein: & $\begin{array}{l}\text { bl ashgar... } \\
\text { (of trees...) }\end{array}$ & بالأشجار & Zein is repeats. \\
\hline 26. & Fatima: & $\begin{array}{l}\text {...yes/we have three different types of forests in } \\
\text { Sweden thalath anwaa } \\
\text { (...yes/we have three different types of forests in } \\
\text { Sweden three types) }\end{array}$ & 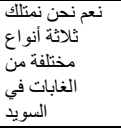 & $\begin{array}{l}\text { Fatima answers quickly, and } \\
\text { then she continues to read and } \\
\text { explain. }\end{array}$ \\
\hline & & & إثلاثة أنواع & \\
\hline $\begin{array}{l}{[45: 34-} \\
45: 44]\end{array}$ & & $(\ldots)$ & & $\begin{array}{l}\text { Fatima asks Hanan to } \\
\text { continue with the translation } \\
\text { of the text into Arabic. }\end{array}$ \\
\hline 27. & Hanan: & shall I say those three & & $\begin{array}{l}\text { Hanan asks what she is going } \\
\text { to translate. }\end{array}$ \\
\hline 28. & Fatima: & $\begin{array}{l}\text { no hai el kilma eli ultah we have three different } \\
\text { forests in Sweden } \\
\text { (no this word that you have said we have three } \\
\text { different forests in Sweden) }\end{array}$ & 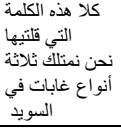 & $\begin{array}{l}\text { Fatima explains to Hanan that } \\
\text { she will only translate the text } \\
\text { literally, not name the three } \\
\text { different types of forests. }\end{array}$ \\
\hline 29. & Hanan: & $\begin{array}{l}\text { andana thalathat anwaa men alshagar fi } \\
\text { (we have three different types of trees in } \\
\text { [Sweden]) }\end{array}$ & 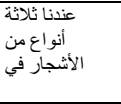 & $\begin{array}{l}\text { Hanan translates into Arabic. } \\
\text { In the translation, she } \\
\text { exchanges the word 'forests' } \\
\text { to 'trees'. }\end{array}$ \\
\hline
\end{tabular}

Fig. 4 Excerpt 3: 140513D2 [45:05-45:51]; Zein, Nour, Haydar, Hanan and Halima and the mother tongue teacher (Fatima)

Through the multilingual study guidance, the students are given support in understanding the text. As in excerpt 2 (Fig. 3), there is a tendency to simplify the content and language. Instead of giving the students the Arabic word ghabe (forest) as a linguistic tool to understand the difference between forests and trees, the word forest is explained with the phrases: lots of trees (23), and full of trees (24). This means that the students who are not yet able to independently read the text in Swedish risk being limited to using everyday language in this learning situation, so they miss the linguistic tools that a subject-specific language usage constitutes in this language game. Providing students such as Halima and Haydar access to this could be achieved if, for example, they had received the written text in both Arabic and Swedish.

\section{A conversation with Halima}

Excerpt 4 (Fig. 5) shows parts of a conversation between Halima, the mother tongue teacher (Fatima), and the first author of this article (Annika) (May 28, 2015), 1 year after the situations in Excerpts 1-3. In the conversation, Halima describes how she experiences 


\begin{tabular}{|c|c|c|c|c|}
\hline Turn & Person & Transcription & Arabic & Contextual description \\
\hline 30. & Halima: & $\begin{array}{l}\text { I think that in [Halima's native country] there is } \\
\text { good biology/here... }\end{array}$ & & $\begin{array}{l}\text { Halima starts to answer but is } \\
\text { interrupted by Annika. }\end{array}$ \\
\hline 31. & Annika: & ..biology & & $\begin{array}{l}\text { Annika asks if Halima means } \\
\text { biology. }\end{array}$ \\
\hline 32. & Halima: & yes here it is easy & & $\begin{array}{l}\text { Halima confirms that she } \\
\text { means biology and that it is } \\
\text { easy here in Sweden. }\end{array}$ \\
\hline $\begin{array}{l}{[15: 29-} \\
15: 53]\end{array}$ & & $(\ldots)$ & & $\begin{array}{l}\text { The mother-tongue teacher } \\
\text { asks Halima in Arabic why } \\
\text { she thinks it is easier in } \\
\text { Sweden. }\end{array}$ \\
\hline \multirow[t]{2}{*}{33.} & Halima: & $\begin{array}{l}\text { honak kol shi el bealmoh ahyaa jeded/hna kol } \\
\text { shi bealmoh baarfah }\end{array}$ & الألى كل شئموه & Halima answers. \\
\hline & & $\begin{array}{l}\text { (everything they teach us there are new } \\
\text { things/everything they teach us here I already } \\
\text { know) }\end{array}$ & 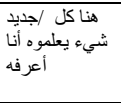 & \\
\hline 34. & Fatima: & $\begin{array}{l}\text { oh well hek asdek okey hm okey } \\
\text { (oh well is that what you mean okay hm okay) }\end{array}$ & هذا هو قصدك نعم & Fatima sounds surprised. \\
\hline 35. & Annika: & what & & $\begin{array}{l}\text { Annika is wondering about } \\
\text { what Halima said in Arabic. }\end{array}$ \\
\hline 36. & Fatima: & $\begin{array}{l}\text { honak kol eshi betaarfih so there it was something } \\
\text { new to her but here it is some kind of repetition } \\
\text { from my point of view [she says] } \\
\text { (there you know everything so there it was } \\
\text { something new for her but here it is some kind of } \\
\text { repetition from my point of view [she says]) }\end{array}$ & هناك كل شيء & $\begin{array}{l}\text { The mother-tongue teacher } \\
\text { completes her response to } \\
\text { Halima and then translates } \\
\text { and explains what Halima had } \\
\text { said to Annika. }\end{array}$ \\
\hline $\begin{array}{l}{[16: 10-} \\
19: 07]\end{array}$ & & $(\ldots)$ & & $\begin{array}{l}\text { Halima is asked how she } \\
\text { knows the aim of the lesson } \\
\text { and how to achieve this. } \\
\text { Halima answers that she } \\
\text { thinks she learns by listening } \\
\text { to her classmates. She also } \\
\text { expresses that the teachers' } \\
\text { focus on those students with } \\
\text { limited possibility to express } \\
\text { themselves in Swedish is } \\
\text { important. }\end{array}$ \\
\hline 37. & Halima: & $\begin{array}{l}\text { ja bejiboli walad o bent bearfo arabi kano } \\
\text { besaadoni Iman bl dares al swedi yaani } \\
\text { besaadoni ana bahkilhom bl arabi o homa } \\
\text { beyahko bl swedi } \\
\text { (yes they bring me a boy and a girl who know } \\
\text { Arabic they used to help me in the Swedish } \\
\text { lesson they help me I speak Arabic with them } \\
\text { and they speak Swedish) }\end{array}$ & 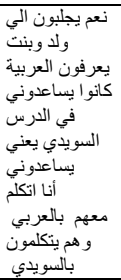 & $\begin{array}{l}\text { Halima explains that her } \\
\text { Arabic-speaking classmates } \\
\text { help her in the Swedish } \\
\text { lessons, that she speaks } \\
\text { Arabic and they speak } \\
\text { Swedish. }\end{array}$ \\
\hline
\end{tabular}

Fig. 5 Excerpt 4: 150528D [15:21-19:19]; A conversation with Halima

the school and education in Sweden and the support she receives from her teachers and classmates. She explains that she has been taught science in her native country and gives some examples: blood circulation; fungi and toadstools; the water cycle; and photosynthesis. Halima is also asked about the difference between the science teaching in Sweden and in her native country.

Considering Halima's prior learning about photosynthesis, Furkan and Adnan could have related to the photosynthesis when explaining to Halima what needles are in Excerpt 2 (Fig. 3); and that needles and leaves have the same function in photosynthesis; and that both needles and leaves contain chlorophyll but look different, depending on adaptation to the environment in which they grow. However, concepts such as photosynthesis and 
chlorophyll are neither included in the written nor in the oral text in the lesson. Halima and the other students have no access to these concepts that could have been important tools to fill the gaps that the students encounter when reading the text. It is uncertain why these concepts are not addressed. It may be related to the general low expectations of students who do not yet have sufficient access to the language of instruction (Van Laere et al. 2014). As a consequence, subject-specific concepts and words are unconsciously or consciously ignored, rather than used to better understand the subject matter. If so, the subject content risks being simplified and adapted to the students' linguistic ability in the language of instruction and their ability to use all language resources to create continuity in science learning and develop a deeper understanding of the subject matter is not utilized.

Halima describes that she learns through listening to her classmates and that they serve as interpreters for her in learning situations (37). Furthermore, she emphasizes the teachers' support as important. However, in this situation, this seems insufficient to fill the gap that occurs when she and the other students encounter the Swedish word barrskog (coniferous forest). The students probably do not know corresponding words for coniferous forest or needles in Arabic and also fail to explain this to Halima in another way, resulting in a linger gap. However, if the students had knowledge about and access to concepts such as photosynthesis and chlorophyll, it might have helped them explain the relationship between needles and leaves for Halima in a language game with which she has prior experience, and the language games of science could have continued. In such a language game, the subject-specific words and concepts used in Swedish can be translated into Arabic using a Swedish-Arabic dictionary. Halima perceives the science education in Sweden to be not as advanced as the scientific education she received in her native country (33). This indicates that Halima probably has prior experience of many subject-specific words and concepts, such as photosynthesis, needle and coniferous forest. Therefore, a translation of these words from Swedish into Arabic probably would have been beneficial in this situation. Furthermore, multimodal resources that visualize the science content, such as the taxonomy of some tree species in different types of forests or close-up pictures of a leaf and a needle, would probably provide support for the students in this learning situation.

\section{Possible implications for science learning in multilingual science classrooms}

In this article, we argue that a translanguaging science classroom (TSC) generally offers multilingual students increased opportunity to relate the subject matter to their first language and prior experience. These results are also partly confirmed in our previous studies (Karlsson et al. 2018) and in some other studies in the field (e.g., Stevenson 2013). Our results also imply that a TSC improves the probability that students' understanding of the subject will increase and seems to create a space in the multilingual classroom in which the students are able to relate their everyday experiences to the science subject matter. This also seems to create a desire to continue learning, which contributes to continuity and empowers science learning. For example, several of our chosen excerpts indicate that encouraging students to use all their linguistic resources in learning processes facilitates building links and relationships between their different languages and the science subject matter.

However, we can also detect that problems may occur if the instruction only encouraging multilingual students to use all their linguistic resources without focusing on the 
differences between discursive and national languages that can emerge in such a situation. To create the best possible conditions for multilingual students, other learning conditions must be met to fully utilize the opportunities from a TSC and our analyses indicate several areas of development in this classroom. These may defined by the fact that the continuity of the students' learning is occasionally disturbed. One obvious area for this, throughout the material, is that concepts and words in both languages often tends to be simplified, both in written and oral texts. An example is the lack of focus on the subject-specific concepts photosynthesis and chlorophyll, both in Swedish and Arabic (Excerpt 2, Fig. 3). These concepts could have been useful conceptual and linguistic tools to explain what needles are, especially considering Halima's prior experience with learning about photosynthesis. This absence of useful conceptual tools that describe the science content in a functional manner (Halliday 1998) is unfortunately common throughout the material. We argue that the tendency of simplification has important and severe consequences for the continuity of science learning in classroom activities.

Simplifying the languages also occurs in multilingual study guidance. An example of this is discovered when the mother tongue teacher translates the written text from Swedish into oral Arabic in Excerpt 3 (Fig. 4). In this translation and transformation of the text from an academic discourse in Swedish to an everyday discourse in Arabic, the word forest becomes transformed to full of trees, which seems to create a linger gap that disturbs the activity. These results indicate that students such as Halima and Haydar have limited access to subject-specific words and concepts that constitute the science subject matter-tools that are useful in the language games (Wittgenstein 1967) used in the language games of science (Wickman 2013). In this way, Halima and Haydar are referred to only learn through an everyday discourse, which provide them limited possibilities to express and convey "the specialized knowledge of science" (Fang 2006, p. 494).

Another reason for gaps and lack of continuity in science learning may be if the science content is only related to an everyday experience or cultural tradition that the teachers and students do not share. An example of this is when the concept coniferous forest is related to Christmas tree in Excerpt 2 (Fig. 3). In addition, the students may mainly use their first language in everyday contexts. Therefore, they may have difficulty understanding the language of instruction when it relates to an everyday use. This means that contextualizing the science subject to everyday and practical experiences may not always provide support for multilingual students, but instead rather complicate their understanding of the subject matter.

However, the results from our analyses clearly display that the students' ability to use both first and second languages in multilingual science classroom activities becomes an important resource in their appropriation of a new social practice. The gaps, which the students encounter, for example in Halima's appropriation (Fig. 2), are filled by creating relationships between words and expressions in both Arabic and Swedish. In this way, the possibility to create and tie relations between the languages seems crucial for creating 
continuity of the activity, creating links between concepts and making it possible for the students to explain and understand how to speak, think and act in this TSC. In this way, a TSC facilitates multilingual students' empowerment in science education. Additionally, the results indicate that the continuity of science learning also creates continuity in the appropriation of the language of instruction. Therefore, the scientific subject matter becomes a tool for appropriating both the subject-specific language and the national language of instruction. This can be related to Jenny Nilsson Folke's (2017) research about learning and inclusion among newly arrived students, which shows that inclusion in a social context promotes language learning and creates better conditions for inclusion.

Finally, we argue that a translanguaging science classroom gives multilingual students greater opportunities to express themselves and participate in science classroom activities. However, there are areas in this practice that need development to create greater opportunities for continuity in science learning for students like Halima and Haydar. All students need access to conceptual and linguistic tools, in everyday and academic discourses, to relate the science subject matter to prior experience in negotiations about the scientific content and its relating language usage, and to participate in arguments and discussions about scientific issues. If concepts and words are missing for expressions in these situations, multimodal resources that illustrate and clarify the subject matter are required to maximize all students' learning.

Acknowledgements We would like to thank the teachers and the students who participated in this study. We are also grateful for all the help we received from Haddel Ali Shoker with the Arabic translation.

Funding This work was financially supported by the Swedish Research Council (ref. 721-2014-2015); and the research program, perspectives on literacy and inclusive subject teaching in a multilingual society (LIT), Malmö University.

Open Access This article is distributed under the terms of the Creative Commons Attribution 4.0 International License (http://creativecommons.org/licenses/by/4.0/), which permits unrestricted use, distribution, and reproduction in any medium, provided you give appropriate credit to the original author(s) and the source, provide a link to the Creative Commons license, and indicate if changes were made.

\section{Appendix 1}

Träd

Vi bor i ett land som bestảr av mycket skog. Lite mer än hälften av Sveriges yta är täckt av skog. Vi har tre olika sorters skogar i Sverige, vi har barrskog, lövskog och blandskog. I en barrskog växer det granar och tallar, i en lövskog växer det träd som har blad och i en blandskog är det precis som det låter blandade barr- och lövträd.

Ett träd är som vilken växt som helst och har mảnga likheter med tex en blomma. Bàde träd och blomman har rötter, stam (hos blommor säger vi stjälk), blad och blommor. Den största skillnaden på ett träd och en blomma är trädets storlek. Träden kan bli mycket höga. I Sverige är skogarna ca 25-30 meter höga. Världens högsta träd är 112 meter högt och finns i USA. 


\section{Appendix 2: The speakers' origin utterances in Swedish or Arabic}

(1) low andek bl arabi betroji

(2)

(3) oli shi / lazem etoli shi ala al shajara

(4) bedek takhehe waket o tfakre shwai

(5)

(6) Furkan kef yaani

(7) rah naqraa waraqa an al alshagrara

(8) yaani lazem enti etfakri kel shi eli fiha al shagara o when betkon

(10) bedek etgoli she

(11) la khalas laa

(12) lazem yani ashan taaraf al moalema men ali haka w men eli ma haka

(13) goli mathHanan gadesh al shagra omrha goli bs haik

(14) Halima har du något mer

(15) when tenmo al shagara

(16) fi shagara / yanni endaha hai al löv / bs

(17) al warak

(18) bs al warak bs bl al barr / fi menon andon hårda pinnar haiek hårda pinnar / fahmti

(20) ...al assyat al qauia...

(21) ...vet hon vad en julgran är

(22) okej bshrahlekom jaha bl arabi w baaden btshofonha kef tehkonha bl swedi

(23) består av mycket skog yaani beniesh fi balad mantaqa fiha shagar keter

(24) lite mer än hälften av Sveriges yta består av skog yaani taqriban noss al swed malian bl alshgar

(25) bl alashgar...

(26) ...ja vi har tre olika sorters skogar i Sverige thalath anwaa

(27) ska jag säga dom tre

(28) nej hai el kilma eli ultah vi har tre olika skogar i Sverige

(29) andana thalathat anwaa men alshagar fi

(30) jag tror det i [det land som Halima tidigare gått i skola i] det är bra biologi här...

(31) ...biologi

(32) ja här det är lätt

(33) honak kol shi el bealmoh ahyaa jeded / hna kol shi bealmoh baarfah

(34) jaha hek asdek okej hm okej

(35) vad då

(36) honak kol eshi betaarfih alltså där det var något nytt för henne men här det blir någon slags repetition för min del

(37) ja bejiboli walad o bent bearfo arabi kano besaadoni Iman bl dares al swedi yaani besaadoni ana bahkilhom bl arabi o homa beyahko bl swedi

\section{References}

Bakhtin, M. (1981). The dialogic imagination: Four essays. Austin: University of Texas Press.

Bakhtin, M. (1986). Speech genres and other late essays. Austin: University of Texas Press.

Brown, B. A., Cooks, J., \& Cross, K. (2016). Lyricism, identity, and the power of lyricism as the third space. Science Education, 100(3), 437-458. https://doi.org/10.1002/sce.21212.

Brown, B. A., \& Spang, E. (2008). Double talk: Synthesizing everyday and science language in the classroom. Science Education, 92(4), 708-732. https://doi.org/10.1002/sce.20251.

Bryman, A. (2015). Social research methods. Oxford: Oxford University Press.

Buxton, C. A., \& Lee, O. (2014). English learners in science education. In N. G. Lederman \& S. K. Abell (Eds.), Handbook of research on science education (pp. 204-222). New York: Routledge. 
Cummins, J. (2017). Teaching minoritized students: Are additive approaches legitimate? Harvard Educational Review, 87(3), 404-425.

Danielsson, K. (2016). Modes and meaning in the classroom-The role of different semiotic resources to convey meaning in science classrooms. Linguistics and Education, 35, 88-99. https://doi. org/10.1016/j.linged.2016.07.005.

Dewey, J. (1902). The child and the curriculum. Chicago: University of Chicago Press.

Dewey, J. (1925/1995). Experience and nature. New York: Dover.

Dewey, J. (1938/1997). Experience and education. New York: Touchstone, Simon and Schuster.

Fang, Z. (2005). Scientific literacy: A systemic functional linguistics perspective. Science Education, 89(2), 335-347. https://doi.org/10.1002/sce.20050.

Fang, Z. (2006). The language demands of science reading in middle school. International Journal of Science Education, 28(5), 491-520. https://doi.org/10.1080/09500690500339092.

García, O., \& Kano, N. (2014). Translanguaging as process and pedagogy: Developing the English writing of Japanese students in the US. In J. Conteh \& G. Meier (Eds.), The multilingual turn in languages education: Benefits for individuals and societies (pp. 258-277). Clevedon: Multilingual Matters.

García, O., \& Wei, L. (2014). Translanguaging: Language, bilingualism and education. Basingstoke: Palgrave Macmillan.

Gutierrez, K., Rymes, B., \& Larson, J. (1995). Script, counterscript, and underlife in the classroom: James brown versus brown v. board of education. Harvard Educational Review, 65(3), 445-472. https://doi. org/10.17763/haer.65.3.r16146n25h4mh384.

Hajer, M., \& Meestringa, T. (2014). Språkinriktad undervisning: En handbok [Language-based education: A handbook] (2nd ed.). Stockholm: Hallgren \& Fallgren.

Halliday, M. (1998). Things and relations. Regrammaticising experience as technical knowledge. In J. Martin \& R. Veel (Eds.), Reading science. Critical and functional perspective on discourses of science (pp. 185-235). London: Routledge.

Halliday, M., \& Martin, J. (1993). Writing science: Literacy and discursive power. Pittsburgh: University of Pittsburgh Press.

Hamza, K. M., \& Wickman, P. (2009). Beyond explanations: What else do students need to understand science? Science Education, 93(6), 1026-1049. https://doi.org/10.1002/sce.20343.

Jakobson, B., \& Axelsson, M. (2017). Building a web in science instruction: Using multiple resources in a Swedish multilingual middle school class. Language and Education, 31(6), 479-494. https://doi. org/10.1080/09500782.2017.1344701.

Jakobsson, A. (2012). Sociokulturella perspektiv på lärande och utveckling: Lärande som begreppsmässig precisering och koordinering [Sociocultural perspectives on learning and development: Learning as conceptual clarification and coordination]. Pedagogisk Forskning I Sverige, 17(3-4), 152-170.

Jakobsson, A., Mäkitalo, Å., \& Säljö, R. (2009). Conceptions of knowledge in research on students' understanding of the greenhouse effect: Methodological positions and their consequences for representations of knowing. Science Education, 93(6), 978-995. https://doi.org/10.1002/sce.20341.

Kamberelis, G., \& Wehunt, M. D. (2012). Hybrid discourse practice and science learning. Cultural Studies of Science Education, 7(3), 505-534. https://doi.org/10.1007/s11422-012-9395-1.

Karlsson, A., Nygård Larsson, P., \& Jakobsson, A. (2016). Flerspråkighet som en resurs i NO-klassrummet [Multilingualism as a resource in the science classroom]. Pedagogisk Forskning $i$ Sverige, 21(1-2), 30-55.

Karlsson, A., Nygård Larsson, P., \& Jakobsson, A. (2018). Multilingual students' use of translanguaging in science classrooms. International Journal of Science Education. https://doi.org/10.1080/09500 693.2018.1477261.

Kelly, G. J. (2011). Scientific literacy, discourse, and epistemic practices. In C. Linder, L. Östman, D. A. Roberts, P. Wickman, G. Ericksen, \& A. MacKinnon (Eds.), Exploring the landscape of scientific literacy (pp. 61-73). New York: Routledge.

Kelly, G. J., McDonald, S., \& Wickman, P. (2012). Science learning and epistemology. In K. Tobin, B. J. Fraser, \& C. J. McRobbie (Eds.), Second international handbook of science education (pp. 281-291). Dordrecht: Springer.

Lee, O. (2005). Science education with English language learners: Synthesis and research agenda. Review of Educational Research, 75(4), 491-530. https://doi.org/10.3102/00346543075004491.

Lemke, J. (1990). Talking science: Language, learning, and values. Norwood: Ablex Publishing Company.

Lidar, M., Almqvist, J., \& Östman, L. (2010). A pragmatist approach to meaning making in children's discussions about gravity and the shape of the earth. Science Education, 94(4), 689-709. https://doi. org/10.1002/sce.20384.

Linell, P. (2009). Rethinking language, mind, and world dialogically: Interactional and contextual theories of human sense-making. Charlotte, NC: Information Age Publ. 
Marcus, G. E. (1995). Ethnography in/of the world system: The emergence of multi-sited ethnography. Annual Review of Anthropology, 24, 95-117. https://doi.org/10.1146/annurev.an.24.100195.000523.

Mehan, H. (1979). 'What time is it, Denise?' Asking known information questions in classroom discourse. Theory into Practice, 18(4), 285-294. https://doi.org/10.1080/00405847909542846?journalCod e=htip20.

Mondada, L. (2006). Video recording as the reflexive preservation and configuration of phenomenal features for analysis. In H. Knoblauch, J. Raab, H. G. Soeffner, \& B. Schnettler (Eds.), Video analysis (pp. 51-68). Bern: Peter Lang.

Msimanga, A., \& Lelliott, A. (2014). Talking science in multilingual contexts in South Africa: Possibilities and challenges for engagement in learners home languages in high school classrooms. International Journal of Science Education, 36(7), 1159-1183. https://doi.org/10.1080/09500693.2013.851427.

Nilsson Folke, J. (2017). Lived transitions: Experiences of learning and inclusion among newly arrived students. Stockholm: Stockholm University.

Nygård Larsson, P. (2011). Biologiämnets texter: Text, språk och lärande i en språkligt heterogen gymnasieklass [The biology subject's texts: Text, language and learning in a linguistic heterogeneous high school class]. Malmö: Malmö University.

Olander, C. (2010). Towards an interlanguage of biological evolution: Exploring students' talk and writing as an arena for sense-making. Gothenburg: Göteborg University.

Östman, L., \& Wickman, P. (2014). A pragmatic approach on epistemology, teaching, and learning. Science Education, 98(3), 375-382. https://doi.org/10.1002/sce.21105.

Piqueras, J., Hamza, K. M., \& Edvall, S. (2008). The practical epistemologies in the museum: A study of students' learning in encounters with dioramas. Journal of Museum Education, 33(2), 153-164. https ://doi.org/10.1080/10598650.2008.11510596.

Quigley, C. (2011). Pushing the boundaries of cultural congruence pedagogy in science education towards a third space. Cultural Studies of Science Education, 6(3), 549-557. https://doi.org/10.1007/s1142 2-011-9335-5.

Reath Warren, A. (2016). Multilingual study guidance in the Swedish compulsory school and the development of multilingual literacies. Nordand, 11(2), 115-142.

Roth, W., \& Jornet, A. (2014). Toward a theory of experience. Science Education, 98(1), 106-126. https:// doi.org/10.1002/sce.21085.

Säljö, R. (2010). Lärande och kulturella redskap: Om lärprocesser och det kollektiva minnet. Stockholm:Norstedt.

Seah, L. H., Clarke, D. J., \& Hart, C. E. (2014). Understanding the language demands on science students from an integrated science and language perspective. International Journal of Science Education, 36(6), 952-973. https://doi.org/10.1080/09500693.2013.832003.

Serder, M., \& Jakobsson, A. (2016). Language games and meaning as used in student encounters with scientific literacy test items. Science Education, 100(2), 321-343. https://doi.org/10.1002/sce.21199.

Stevenson, A. R. (2013). How fifth grade Latino/a bilingual students use their linguistic resources in the classroom and laboratory during science instruction. Cultural Studies of Science Education, 8(4), 973989. https://doi.org/10.1007/s11422-013-9522-7.

Tan, E., Barton Calabrese, A., Turner, E., \& Gutiérrez, M. V. (2012). Empowering science and mathematics education in urban schools. Chicago: University of Chicago Press.

Thomas, W. P., \& Collier, V. (1997). School effectiveness for language minority students. NCBE Resource Collection Series, No. 9. Washington, DC: George Washington University.

Ünsal, Z., Jakobson, B., Molander, B., \& Wickman, P. (2017). Language use in a multilingual class: A study of the relation between bilingual students' languages and their meaning-making in science. Research in Science Education. https://doi.org/10.1007/s11165-016-9597-8.

Ünsal, Z., Jakobson, B., Wickman, P., \& Molander, B. (2018). Gesticulating science: Emergent bilingual students' use of gestures. Journal of Research in Science Teaching, 55(1), 121-144. https://doi. org/10.1002/tea.21415.

Van Laere, E., Aesaert, K., \& van Braak, J. (2014). The role of students' home language in science achievement: A multilevel approach. International Journal of Science Education, 36(16), 2772-2794. https:// doi.org/10.1080/09500693.2014.936327.

Wallace, C. S. (2004). Framing new research in science literacy and language use: Authenticity, multiple discourses, and the "third space". Science Education, 88(6), 901-914. https://doi.org/10.1002/ sce. 20024.

Warren, B., Ballenger, C., Ogonowski, M., et al. (2001). Rethinking diversity in learning science: The logic of everyday sense-making. Journal of Research in Science Teaching, 38(5), 529-552. https://doi. org/10.1002/tea.1017. 
Wei, L. (2011). Moment analysis and translanguaging space: Discursive construction of identities by multilingual Chinese youth in Britain. Journal of Pragmatics, 43(5), 1222-1235. https://doi.org/10.1016/j. pragma.2010.07.035.

Wickman, P. (2013). Aesthetic experience in science education: Learning and meaning-making as situated talk and action. New York and London: Routledge.

Wickman, P., \& Östman, L. (2002). Learning as discourse change: A sociocultural mechanism. Science Education, 86(5), 601-623. https://doi.org/10.1002/sce.10036.

Wittgenstein, L. (1967). Philosophical investigations. Oxford: Blackwell.

Publisher's Note Springer Nature remains neutral with regard to jurisdictional claims in published maps and institutional affiliations.

Annika Karlsson is a Ph.D. graduate student in the Department of Education and Society at Malmö University in Sweden. Her research focuses on the use of language in meaning-making situations in multilingual science classrooms.

Pia Nygård Larsson has a Ph.D. in Research Education in Swedish and Didactics and is a senior lecturer in Swedish as a second language in the Department of Education and Society at Malmö University in Sweden. Her research focuses on teaching and learning from the perspectives of classroom discourse and development of literacy.

Anders Jakobsson is a professor in Science Education in the Department of Education and Society at Malmö University in Sweden. 